\title{
Feeding goats on scrubby Mexican rangeland and pasteurization: influences on milk and artisan cheese quality
}

\author{
Mario Cuchillo Hilario • Claudia Delgadillo Puga • \\ Nicole Wrage • Fernando Pérez-Gil R.
}

Accepted: 12 February 2010 /Published online: 16 March 2010

(C) The Author(s) 2010. This article is published with open access at Springerlink.com

\begin{abstract}
The objective of this study was to evaluate the effect of foraging on local scrubby rangeland versus stable feeding with high-protein concentrate as well as the compulsory pasteurization process on goats' milk and artisan soft cheese quality in terms of chemical composition and fatty acid profile. The results indicated that there were no significant differences in the energy, fat, or ash content of milk and cheese due to feeding; however, a significant influence of feeding on cheese protein and fatty acids in both milk and cheese was detected. Feeding on scrubby rangeland tended to increase the amounts of major polyunsaturated fatty acids in milk and cheese from goats. Pasteurization, which is mandatory in Mexico, did not alter the fatty acid concentrations in milk or cheese. Small goatkeepers using rangeland resources might claim better economical returns for products recognized as healthier. Further investigations to assure ecosystem sustainability of shrubby rangeland joined with economical evaluations and best animal management to avoid deleterious effects are recommended.
\end{abstract}

Keywords Dairy · Grazing · Fatty acids · Pasteurization · Rangeland

M. C. Hilario • C. D. Puga $(\bowtie) \cdot$ F. Pérez-Gil R.

Animal Nutrition Department, National Institute of Medical

Sciences and Nutrition "Salvador Zubirán",

Vasco de Quiroga 15,

CP. 14000 México D.F. Mexico

e-mail: claudia.delgadillop@quetzal.innsz.mx

e-mail:dpclau@quetzal.innsz.mx

M. C. Hilario $\cdot$ N. Wrage

Department of Crop Science, Institute of Grassland Science,

University of Goettingen,

Von-Siebold-Str. 8,

37075 Goettingen, Germany

\author{
Abbreviations \\ GR cheese made from grazing/browsing goats' raw \\ milk \\ GP cheese made from grazing/browsing goats' pas- \\ teurized milk \\ IR cheese made from indoor goats' raw milk \\ IP cheese made from indoor goats' pasteurized milk \\ CLA conjugated linoleic acid \\ FID flame ionization detector \\ $\mathrm{BF}_{3} \quad$ boron trifluoride
}

\section{Introduction}

Mexico is one of the largest producers of goat milk in the American continent; the goat production sector has increased by $25.8 \%$ between 2000 and 2007 (FAOSTAT 2007). Goat milk is traditionally used for the production of sweets, with an increasing amount of cheese manufacture, principally by smallholders who comprise around $40 \%$ of the goat dairy sector (Galina et al. 2007). The feeding of the animals is traditionally based on local pasture resources (Arriaga-Jordán et al. 2003; Mellado et al. 2006; GarcíaWinder et al. 2009), which may lead to rangeland deterioration due to overgrazing. Therefore, Galina et al. (2007) suggested that feeding with management-intensive supplementation may provide a sustainable alternative for small dairies in Mexico that may allow to meet nutritional requirements of the animals and sustain milk production. This may however have effects on goat milk and cheese quality.

All cheese properties are influenced by the animal species delivering the milk and by their health, by agro-climatic situations, seasonality and feeding conditions (Elgersma et al. 
2006; Hervás et al. 2008; Puga et al. 2009a). Among these factors, animal feeding appears to be most important for milk and cheese quality (Sanz Sampelayo et al. 2007; Vasta et al. 2008), as both the season and the sanitary status of flocks mainly influence the milk quantity produced, while the nature of feeds ingested influences markedly the milk's nutritional and gustative quality (Sanz Sampelayo et al. 2007; Ben Salem et al. 2008).

Pasture-based animal feeding has been found to result in higher contents of healthy compounds in milk than those found in milk from more intensive feeding systems (Morand-Fehr et al. 2007). Phytochemicals like phenols, flavonoids, terpenoids and fatty acids are bioactive compounds present in milk, cheese, and meat foodstuffs (Galina et al. 2007; Vasta et al. 2008; Cuchillo et al. 2010), which could have important implications on human health.

Although extensive studies about animal feeding effects on milk and cheese quality properties have been carried out in temperate latitudes showing the advantages of feeding on pastures (Elgersma et al. 2006; Morand-Fehr et al. 2007; Hervás et al. 2008), the impact of vegetation resources from dry ecosystems on dairy products and animal production are not clear yet. So far, studies carried out in arid regions evaluated either single fodder species (García-Winder et al. 2009) or included various amounts of certain shrubs into the diets of animals (Ben Salem et al. 2008). Besides, the few assessments that included browsing usually tested either milk (Mellado et al. 2006; Hervás et al. 2008) or cheese quality (Puga et al. 2009a, b), but few include evaluations of both milk and cheese. These might however be important to find differences in quality and develop marketing options for farmers in these regions. Thus, the influence of browsing on semiarid rangeland including forage species, cacti, and shrubs on dairy quality parameters needs to be investigated to better understand the potential benefits for small dairies and artisanal cheese manufactures (Galina et al. 2007).

It is regulated by Mexican law (NOM-091-SSA1 1994) that all dairy products have to be produced with pasteurized milk. This compulsory processing of the milk has been suggested to be an important factor by which the quality of cow milk and dairy products is modified (Calligaris et al. 2004). It is feared that the processing may lead to a deterioration of milk and artisanal cheese quality in terms of contents of healthy unsaturated fatty acids. So far, the effect of pasteurization on goat milk from dairies located in arid zones and its products have not been studied in detail.

Although feeding and heat treatment are just two factors that can alter the final milk and cheese composition, these are determinant factors for milk and cheese quality. In the present study, we compared the effect of feeding on local scrubby rangeland with a high-protein stable feeding as well as the compulsory pasteurization process on goats' milk and artisan soft cheese quality in terms of chemical composition and fatty acid profile. We hypothesized that milk and cheese from animals with a rangeland-based diet has higher contents of healthy polyunsaturated fatty acids than that from animals fed on a diet of grain and hay. Pasteurization was hypothesized to decrease the amount of polyunsaturated fatty acids in both milk and cheese.

\section{Materials and methods}

\section{Experimental setup}

The experiment was carried out in Querétaro, Mexico $\left(20^{\circ}\right.$ $35^{\prime}$ Northern latitude, $100^{\circ} 18^{\prime}$ Western longitude; $1,950 \mathrm{~m}$ above sea level), during summer 2007. The climate is dry semiarid with isolated rains in winter and an average annual precipitation of $460 \mathrm{~mm}$. Two feeding treatments were set up with French Alpine goats. After milking, animals in treatment A were allowed to graze and browse freely for $8 \mathrm{~h} \mathrm{day}^{-1}$ on 14 ha of shrubby rangeland, with overnight confinement. They did not receive any supplementary feeding. The semiarid rangeland vegetation was characterized by forbs (e.g., Aristida adscensionis, Bouteloua curtipendula), leguminous trees (e.g., Acacia farnesiana, Acacia schaffneri) and cacti (e.g., Opuntia affasiacantha, Opuntia amyctaea) mainly (Cuchillo et al. 2009; Puga et al. 2009b). Animals in feeding treatment B were kept in full indoor confinement during the study, fed $2.5 \mathrm{~kg}$ DM per animal and day, consisting of $1 \mathrm{~kg}$ grain supplement and $1.5 \mathrm{~kg}$ lucerne hay (Table 1). Material for indoor feeding was harvested (lucerne hay) and prepared (grain concentrate) once for the complete experimental time and stored separately. Rations were prepared daily for each indoor animal group. Grain concentrate consisted of rolled corn

Table 1 Chemical composition of used diets ( $g / 100 \mathrm{~g}$ dry-weight basis)

\begin{tabular}{lccl}
\hline & Grazing/browsing $\operatorname{diet}^{\mathrm{a}}$ & Indoor diet $^{\mathrm{b}}$ & $p$ value \\
\hline Protein & $10.7 \pm 5.5 \mathrm{~b}$ & $19.5 \pm 0.5 \mathrm{a}$ & $* *$ \\
Lipids & $2.1 \pm 1.9$ & $4.8 \pm 0.9$ & $\mathrm{NS}$ \\
Ash content & $12.2 \pm 7.2 \mathrm{a}$ & $7.4 \pm 0.5 \mathrm{~b}$ & $*$ \\
Crude fiber & $21.6 \pm 9.3 \mathrm{a}$ & $15.0 \pm 0.3 \mathrm{~b}$ & $*$ \\
N-free extract & $53.4 \pm 4.4$ & $53.3 \pm 0.1$ & NS \\
\hline
\end{tabular}

Means with different letters indicate differences between columns

$N S$ not significant

${ }^{*} p<0.05 ; * * p<0.001$

${ }^{\mathrm{a}}$ Semiarid rangeland vegetation

${ }^{\mathrm{b}}$ Grain concentrate (rolled corn $55 \%$, wheat bran $17 \%$, barley $15 \%$, soybean $9.3 \%$, and vitamins and minerals $3.7 \%$ ) supplemented with $1.5 \mathrm{~kg}$ lucerne hay 
$55 \%$, wheat bran $17 \%$, barley $15 \%$, soybean $9.3 \%$, and vitamins and minerals $3.7 \%$.

Per feeding trial, there were four groups of animals consisting of five animals each. The animals had an average weight of $50 \pm 5 \mathrm{~kg}$, with a lactation period of 150 days. Goats were milked daily at 7:00 a.m. Milk from each replicate group was collected in a separate container. For five consecutive days, the milk of two groups per feeding trial was analyzed and processed raw, that of the other two was pasteurized before further handling. For pasteurization, the milk was heated to a temperature of $63^{\circ} \mathrm{C}$ for $30 \mathrm{~min}$. Thus, four types of milk were available, resulting also in four different cheeses: GR = grazing/browsing goats' raw milk, GP = grazing/browsing goats' pasteurized milk, IR= indoor goats' raw milk, IP = indoor goats' pasteurized milk.

\section{Analysis of the diets}

Before the feeding trial started and when there were temporarily no animals on the rangeland, herbage was sampled to estimate its gross chemical composition. Samples were taken in three plots of $20 \mathrm{~m}$ by $50 \mathrm{~m}$ randomly distributed on the rangeland (14 ha) with ten subplots $\left(0.5 \mathrm{~m}^{2}\right)$ per plot, i.e., 30 subplots in total. The areas were sampled again at the end of the experiment. Samples for composition analyses of material for indoor feeding were taken at the same time as for the rangeland vegetation (mixture of lucerne hay $60 \%$ and grain supplement $40 \%$ ), i.e., before the feeding trial and at its end (three samples each time). The samples were ground to a particle size of $1 \mathrm{~mm}$ and analyzed as follows: Moisture (ovendrying at $60^{\circ} \mathrm{C}$ ), fat, crude fiber, and ash content (burning at $550^{\circ} \mathrm{C}$ in an electrical furnace) were determined using standard methods (AOAC 2003). Nitrogen was measured using the micro-Kjeldahl technique (AOAC 2003). To this end, $\mathrm{N}$-free extract was calculated as the difference between $100 \%$ and the summed moisture, protein (nitrogen content times 6.25), fat, crude fiber, and ash percentages. Gross energy was determined using the calorimetric Parr bomb (Parr Instrument Company, IL, USA). All samples were analyzed three times.

\section{Conventional cheese manufacture}

To prepare the cheese, milk was mixed with $100 \mathrm{ml}$ of whey lactic acid bacteria suspension (Lactobacillus brevis and Lactobacillus plantarum $10^{5} \mathrm{CFU} / \mathrm{ml}$ ) saved from the previous day (taken directly from the container of the day curd, kept at room temperature). Rennet commercial starter $(1 \mathrm{ml})$ was added, all mixed thoroughly and left to curdle for $24 \mathrm{~h}\left(18-24^{\circ} \mathrm{C}\right)$. Afterwards, the curd ( $\left.\mathrm{pH} 4.3\right)$ was scooped out into cheese cloths to drain for $48 \mathrm{~h}$, hand salted (14 g $\mathrm{NaCl})$ and molded for $24 \mathrm{~h}$. Then, cheese samples of $100 \mathrm{~g}$ each were packed manually using rod shapes with polyolefin shrink wrap for analyses. All milk and cheese samples for later chemical analyses were kept frozen at $-18^{\circ} \mathrm{C}$. The milk was frozen at $-80^{\circ} \mathrm{C}$, lyophilized and stored at $4{ }^{\circ} \mathrm{C}$ for later analysis (Labconco Freezone 6, Labconco Corp., Kansas City, MO, USA); cheese samples were thawn preceding the analysis at room temperature $\left(23^{\circ} \mathrm{C}\right)$. Ten parallel samples of milk and cheese per single treatment were analyzed three times each.

Analysis of milk and cheese

Nitrogen, ash content, and gross energy of milk and cheese samples were analyzed as explained for vegetation samples above. Total milk and cheese fat were determined according to Folch et al. (1957), using chloroform-methanol as a solvent, and a gravimetric calculation. Cholesterol was measured by the procedure described by Fenton and Sim (1991), with direct saponification using 5- $\alpha$-cholestane (96\% Sigma-Aldrich Inc., St. Louis, MO, USA) as the internal standard and gas chromatography with a Varian 3400 CX chromatograph (Varian, Inc., Palo Alto, CA, USA) equipped with a split injector and a flame ionization detector (FID). Final cholesterol determination was performed in a DB- 5 capillary column $(3 \mathrm{~m} \times 0.25 \mathrm{~mm}$ inner diameter), with a film thickness of $0.25 \mu \mathrm{m}$ in an autosampler Model 8200 CX. Column temperatures were held for $1 \mathrm{~min}$ at $180^{\circ} \mathrm{C}$ and increased afterwards at a rate of $40^{\circ} \mathrm{C} / \mathrm{min}$ to a final temperature of $290^{\circ} \mathrm{C}$. The injector and detector temperatures were kept at $280^{\circ} \mathrm{C}$ and $300^{\circ} \mathrm{C}$, respectively. Nitrogen was used as a carrier gas at a flow rate of $30 \mathrm{ml} / \mathrm{min}$. The total retention time was $5 \mathrm{~min}$, and cholesterol quantification was processed with the Varian Star Chromatography Workstation Software version 4.51. The results were expressed in percentage of fat of the sample on a dry-weight basis.

Fatty acid methyl esters in milk and cheese samples

Lipids were dissolved in hexane and sodium hydroxide methanol solutions for saponification. Transetherification of milk and cheese fat to methyl esters were carried out according to the official method 696.33, AOAC (2003), using boron trifluoride $\left(\mathrm{BF}_{3}\right)$. Fatty acid methyl esters (FAME) were quantified by gas chromatography (Varian, Inc., Palo Alto, CA, USA) using a CP-3380 chromatograph equipped with a split injector, FID, and an autosampler CP 8400 , in a DB 23 column $(30 \mathrm{~m} \times 0.25 \mathrm{~mm}$ inner diameter; Varian, Inc., Palo Alto, CA, USA) with a film thickness of $0.25 \mu \mathrm{m}$. Nitrogen was used as the carrier gas at a flow rate of $30 \mathrm{ml} / \mathrm{min}$. The column temperature was held for $1 \mathrm{~min}$ at $120^{\circ} \mathrm{C}$, then increased at a rate of $10^{\circ} \mathrm{C} / \mathrm{min}$ to $200^{\circ} \mathrm{C}$, and finally at $5^{\circ} \mathrm{C} / \mathrm{min}$ to $230^{\circ} \mathrm{C}$. The injector and FID 
temperatures were $250^{\circ} \mathrm{C}$ and $300^{\circ} \mathrm{C}$, respectively. Integration for each fatty acid was performed with a Varian Star Chromatography Workstation Software version 4.51. Identification of the peaks was made on the basis of retention times of standard methyl esters of each individual fatty acid (FAME mix C4-C24 no. 18919-1 AMP; Sigma-Aldrich Inc., St. Louis, MO, USA). Conjugated linoleic acid (CLA) in particular was identified using a CLA methyl ester standard with a mixture of cis- and trans-9,11-, and -10,12octadecadienoic acids (Cat. no. O5632. Sigma-Aldrich Co., USA). Myristoleic acid (C:14 9-tetradecenoic acid; Cat. no. M3525 Sigma-Aldrich Co., USA) was added to the methylated milk and cheese fat samples prior to GC analysis and was used as an internal standard for the chromatographic analysis.

\section{Statistical analysis}

Results of three measurements per sample were averaged before further statistical assessment. The results were analyzed with a Completely Random Variance Analysis in a $2 \times 2$ factorial arrangement, with two feeding treatments (A and B) and two milk processing treatments (raw and pasteurized). Days were treated as repeated measures. Comparison of the means with a significant difference $(\alpha=0.05)$ was established by Tukey's test. All data were analyzed using the general linear model for Statistical Analysis System Program (SAS 2003).

\section{Results}

Table 1 shows the chemical composition of the different diets. The total protein content of the indoor diet was $19.5 \mathrm{~g} / 100 \mathrm{~g}$ whereas that of the grazing diet was $10.7 \mathrm{~g} / 100 \mathrm{~g}$. Conversely, the crude fiber content and the ash content were smaller in the indoor (15.0 and $7.4 \mathrm{~g} / 100 \mathrm{~g}$ for fiber and ash, respectively) compared with the grazing diet $(21.6$ and $12.2 \mathrm{~g} / 100 \mathrm{~g}$, respectively). The content of lipids and the $\mathrm{N}$-free extract did not differ significantly between the diets.

The protein content of cheeses was significantly larger when animals were fed grain and lucerne hay than when they grazed (Table 2). A trend toward higher protein contents could also be seen in the milk of animals receiving indoor diets, but this was not significant. Pasteurization did not have a significant effect on the protein content of either milk or cheese. There were no significant differences in the ash or energy content of milk or cheese from animals with different diets. Also pasteurization did not have a significant influence on these components. The fat content tended to be increased in the products from grazing/browsing animals, but this trend was not significant. Again, pasteurization did not have a clear effect. The milk cholesterol concentrations were smaller in the pasteurized milk of animals fed grain and lucerne hay than in all other cases. However, cheese manufactured from this milk showed a similar cholesterol concentration as that of the other treatments.

Pasteurization did not have a significant effect on the fatty acid profile of milk or cheese samples (Table 3). The fatty acid profile of milk and cheese samples was however affected by the animal feeding regime. There was a larger amount of C17:0, C18:0, C18:1, C18:2 (cis-9, trans-11; trans-9, cis-11), and in the trend also C22:0 acid in milk and cheeses from goats under grazing. Furthermore, significantly larger contents of C17:1, C18:2 (trans-9,12), C18:3, C20:5, C23:0, and C24:0 methyl fatty acids were found in cheese, but not in the milk, from animals on the rangeland. The content of the fatty acid C20:0 was significantly larger in the milk, but not in the cheese from grazing animals. C10:0, C11:0, C12:0, and C14:0 saturated fatty acid values were larger in milk from animals under

Table 2 Scrubby resources feeding and pasteurization influence on quality of goats' milk and artisan soft cheese in Mexico ( $\mathrm{g} / 100 \mathrm{~g}$ dryweight basis)

\begin{tabular}{|c|c|c|c|c|c|c|c|c|c|c|}
\hline & \multicolumn{5}{|l|}{ Milk } & \multicolumn{5}{|l|}{ Cheese } \\
\hline & GR & GP & IR & IP & $p$ value & GR & GP & IR & IP & $p$ value \\
\hline Protein $^{\mathrm{a}}$ & 27.4 & 26.9 & 28.1 & 29.1 & NS & $30.5 \mathrm{bc}$ & $28.4 \mathrm{c}$ & $32.0 \mathrm{ab}$ & $34.0 \mathrm{a}$ & $*$ \\
\hline Ash & 6.5 & 6.6 & 6.9 & 6.6 & NS & 3.9 & 5.1 & 4.7 & 5.1 & NS \\
\hline Energy $(\mathrm{MJ} / \mathrm{kg} \mathrm{DM})$ & 24.2 & 23.5 & 24.0 & 24.6 & NS & 23.2 & 22.8 & 23.0 & 23.6 & NS \\
\hline Fat & 24.9 & 28.0 & 22.1 & 22.8 & NS & 49.2 & 50.9 & 46.9 & 45.8 & NS \\
\hline Cholesterol (mg/100 g) & $112.7 \mathrm{a}$ & $103.6 \mathrm{a}$ & $122.7 \mathrm{a}$ & $76.3 \mathrm{~b}$ & $* *$ & 155.5 & 187.9 & 185.8 & 204.5 & NS \\
\hline
\end{tabular}

Means with different letters indicate differences between columns

$G R$ grazing/browsing goats' raw milk or cheese made from this, GP grazing/browsing goats' pasteurized milk or cheese made from this, $I R$ indoor goats' raw milk or cheese made from this, $I P$ indoor goats' pasteurized milk or cheese made from this, NS not significant

${ }^{*} p<0.05 ; * * p<0.001$

${ }^{\mathrm{a}}$ Total protein $(\%)$ 


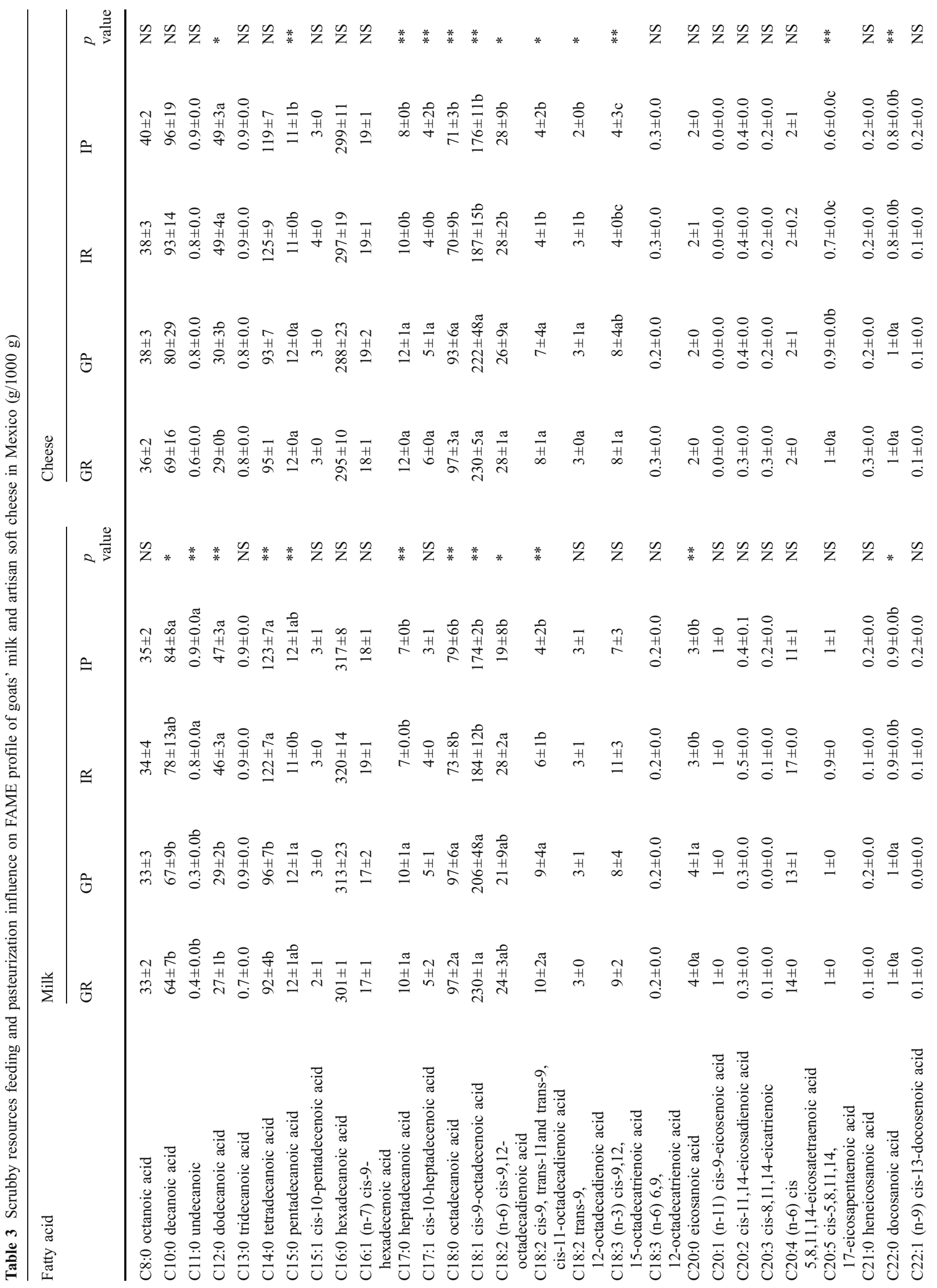




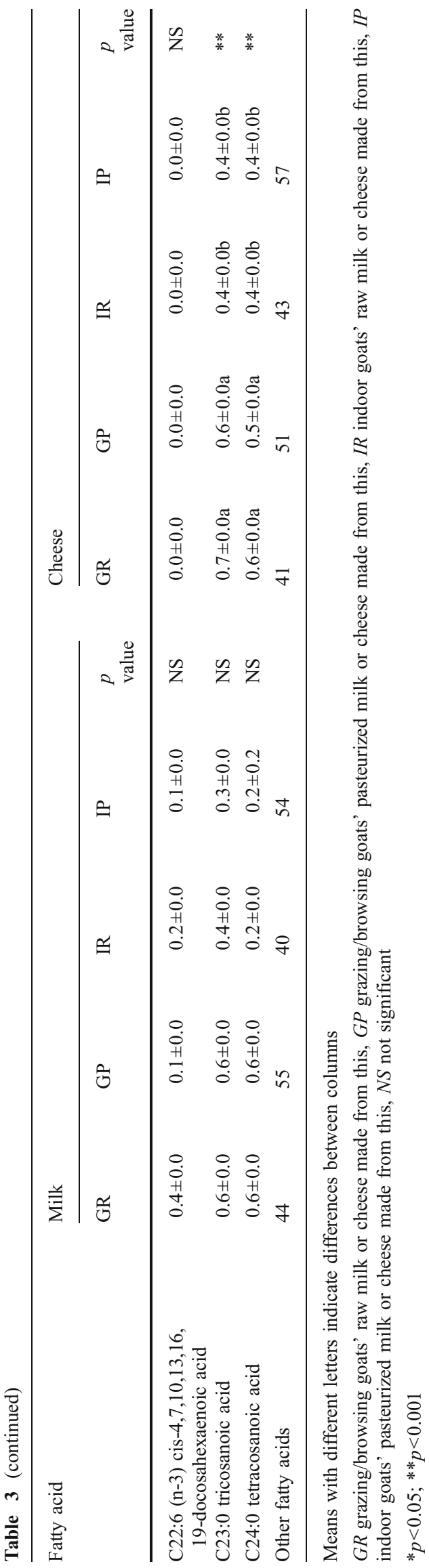

indoor management compared with that from the grazing treatment. For C12:0, this was also true for the cheese prepared from the milk.

\section{Discussion}

We hypothesized that the feeding regime would influence the composition and fatty acid content of goat milk and soft cheese. Interestingly, there were no significant differences in the energy, fat, or ash content in milk and cheese due to feeding; however, a significant influence on cheese protein as well as fatty acids from both milk and cheese was detected. In earlier studies, Morand-Fehr et al. (2007) found that grazing did not affect the milk fat percentage and protein values. Instead, most of the modifications in milk composition were addressed toward a healthier fatty acids profile, which might account for the benefits of fresh herbage and natural pasture-based farming systems that produce milk rich in healthy fat and in micro-components. In the current study, the high-protein concentrate of the indoor group was probably more important for the outcome than the effect of grazing versus confinement.

Caseins and fat molecules move from milk to cheese during the manufacture process and become the main constituents. Therefore, the higher protein content of cheeses when animals were fed grain and lucerne hay than when they grazed may be due to a marginally higher protein content in the same milk, which was, however, not statistically significant. Conversely, Sanz Sampelayo et al. (2007) suggested that a higher protein content of the grain/ hay based diet normally does not translate directly into a higher protein content in milk and cheese. Further studies with different amounts of protein in the diet are needed to resolve this apparent contradiction.

Lipid diet supplementation and high fresh herbage-based diets can modify the nutritional fatty acid profile of milk and cheese, e.g., increase the concentration of cis-9-12octadecadienoic acid (C18:2), cis-9-trans-11, and trans-9cis 11 (C18:2) octadecadienoic acids, which gives to the milk and its products an important hypocholesterolemic value (Elgersma et al. 2006; Galina et al. 2007). The present results are in line with this, as the C18:2 (cis-9trans-11) and C18:2 (trans-9-cis-11) octadecadienoic acids and other important polyunsaturated fatty acids like C18:1 were significantly influenced by feeding; as a result of this, higher values in milk and cheese from rangeland feeding were found. Findings in experiments on milk and cheese with diets rich in seeds and polyunsaturated fatty acids (PUFAs) agree with our results (Luna et al. 2005; Hervás et al. 2008). Puga et al. (2009a) evaluated the effect of season and feeding strategy on the fatty acid composition of raw goat cheese. Their results indicated that the feeding system 
could affect the proportion of desirable fatty acids; i.e., in summer, the monounsaturated and polyunsaturated fatty acid concentrations increased, while they diminished in winter, when plants were dormant and browsing was the major nutritional behavior of the goats. This effect was probably due to a comparatively smaller amount of PUFAs in the vegetation consumed in winter than in summer. Thus, the original concentrations in feeding resources will determine strongly milk and cheese PUFAs concentration, a phenomenon linked with the level of biohydrogenation activity inside the rumen (Morand-Fehr et al. 2007; Sanz Sampelayo et al. 2007).

Our second hypothesis was that pasteurization would influence the composition and fatty acid content of goats' milk and soft cheese. On top of potentially changing the fatty acid profile of milk and cheese, pasteurization may also have other effects that were not evaluated in this study. However, it did not change the gross chemical composition of milk and cheese or the fatty acid profile, but only the content of cholesterol, which was smallest in IP milk. Ebringer et al. (2008) and Calligaris et al. (2004) indicated that the main effects of pasteurization consist in the improvement of food safety and shelf life; this may however have unwanted side effects. Thus, with thermal treatments like ultra high pasteurization $\left(138^{\circ} \mathrm{C}\right.$ to $150^{\circ} \mathrm{C}$ for 1 or $2 \mathrm{~s}$ ), undesirable colors and flavors may develop, including degradation, denaturation, and inactivation of heat sensible components like proteins, vitamins, calcium, iron, zinc, and folic acid. A similar stability of chemical components as in this study was obtained with resembling cheese manufacture (Puga et al. 2009b). Thus, the missing effect of pasteurization could be due to the gentle thermal procedure.

The cholesterol content of soft goat cheese is normally correlated to the total fat content of the used milk (Luna et al. 2005). When a direct correlation beetwen cholesterol concentration and total fat is not found, the phenomenon might be attributed to the heating used: mild heating is not enough to influence the cholesterol concentration, whereas a high thermal treatment promotes the formation of oxysterols, e.g., $\alpha$-epoxy and 7-keto cholesterol, as well as an increase in cholesterol-binding molecules, which may decrease its detectable value (Haddadin 2005). In the current assay, the cholesterol content decreased when the milk from grazing animals was pasteurized (GP).

The results indicated that there were no significant differences in the energy, fat, or ash content of milk and cheese due to feeding; however, a significant influence on cheese protein and fatty acids from both milk and cheese was detected. Cholesterol values were lowest in IP milk. Feeding on scrubby rangeland tended to increase the amounts of major polyunsaturated fatty acids in milk and cheese from goats. Pasteurization, which is mandatory in
Mexico, did not alter the fatty acid concentrations in milk or cheese. Small goat-keepers might claim better economical returns if their products are recognized as healthier. Further investigations to assure ecosystem sustainability of shrubby grazing areas joined with economical evaluations and best animal managing to avoid deleterious effects on the rangeland should be done.

Acknowledgments This works was financed by the Animal Nutrition Department, INCMNSZ. Mario Cuchillo Hilario was supported by a DGRI-SEP grant, Mexico.

Open Access This article is distributed under the terms of the Creative Commons Attribution Noncommercial License which permits any noncommercial use, distribution, and reproduction in any medium, provided the original author(s) and source are credited.

\section{References}

AOAC - Association of Analytical Chemists, 2003. Official Methods of Analysis, 23th Edition, (AOAC, Washington, D. C.)

Arriaga-Jordán, C.M., García-Martínez, A., Albarrán-Portillo, B., Espinoza-Ortega, A., and Castelán-Ortega, O.A., 2003. Feeding strategies for rearing replacement heifers in small-scale dairy production systems in the highlands of central Mexico, Tropical Animal Health and Production, 35, 259-269.

Ben Salem, H., Priolo, A., and Morand-Fehr, P., 2008. Shrubby vegetation and agro-industrial by-products as alternative feed resources for sheep and goats: Effects on digestion, performance and product quality, Animal Feed Science and Technology, 147, 1-2.

Calligaris, S., Manzocco, L., Anese, M., and Nicoli, M.C., 2004. Effect of heat-treatment on the antioxidant and pro-oxidant activity of milk, International Dairy Journal, 14, 421-427.

Cuchillo, H.M., Puga, D.C., Galina, M.A., and Pérez-Gil, R.F., 2009. Influence of semiarid summer browsing on chemical composition in goat's milk cheeses, Tropical and Subtropical Agroecosystems, $11,25-28$.

Cuchillo, H.M., Puga, D.C., Navarro, O.A., and Pérez-Gil, R.F., 2010. Antioxidant activity, bioactive polyphenols in Mexican goats' milk cheeses on summer grazing, Journal of Dairy Research, 77, 20-26.

Ebringer, L., Ferencik, M., and Krajcovic, J., 2008. Beneficial health effects of milk and fermented dairy products - Review, Folia Microbiologica, 53, 378-394.

Elgersma, A., Tamminga, S., and Ellen, G., 2006. Modifying milk composition through forage, Animal Feed Science and Technology, 131, 207-225.

FAOSTAT, 2007. Food and Agriculture Organization of the United Nations. http://faostat.fao.org/default.aspx. Accessed on 5th October, 2009.

Fenton, M., and Sim, J.S., 1991. Determination of egg yolk cholesterol content by on-column capillary gas chromatography, Journal of Chromatography A, 540, 323-329.

Folch, J.M., Less, M., and Sloane-Stanley, G., 1957. A simple method of the isolation and purification of total lipids, Journal of Biological Chemistry, 226, 497-504.

Galina, M.A., Osnaya, F., Cuchillo, H.M., and Haenlein, G.F.W., 2007. Cheese quality from milk of grazing or indoor fed Zebu cows and Alpine crossbred goats, Small Ruminant Research, 71, 264-272. 
García-Winder, L., Goñi-Cedeño, S., Olguín-Lara, P., Díaz-Salgado, G., and Arriaga-Jordán, C., 2009. Huizache (Acacia farnesiana) whole pods (flesh and seeds) as an alternative feed for sheep in Mexico, Tropical Animal Health and Production, 41, 1615-1621.

Haddadin, J.S.Y., 2005. Influence of microwaving and conventional heating of milk on cholesterol contents and cholesterol oxides formation, Pakistan Journal of Nutrition, 4, 85-88.

Hervás, G., Luna, P., Mantecón, Á.R., Castañares, N., de la Fuente, M. A., Juárez, M., and Frutos, P., 2008. Effect of diet supplementation with sunflower oil on milk production, fatty acid profile and ruminal fermentation in lactating dairy ewes, Journal of Dairy Research, 75, 399-405.

Luna, P., Fontecha, J., Juarez, M., and de la Fuente, M., 2005. Changes in the milk and cheese fat composition of ewes fed commercial supplements containing linseed with special reference to the CLA content and isomer composition, Lipids, 40, 445-454.

Mellado, M., Estrada, R., Olivares, L., Pastor, F., and Mellado, J., 2006. Diet selection among goats of different milk production potential on rangeland, Journal of Arid Environments, 66, 127-134.

Morand-Fehr, P., Fedele, V., Decandia, M., and Le Frileux, Y., 2007. Influence of farming and feeding systems on composition and quality of goat and sheep milk, Small Ruminant Research, 68, $20-34$.
NOM-091-SSA1, 1994. Norma Oficial Mexicana, bienes y servicios. Leche pasteurizada de vaca. Disposiciones y especificaciones sanitarias. (Mexican Official Norm goods and services. Pasteurized cow milk. Sanitary requirements and legislation). Diario Oficial de la Federación, Mexico.

Puga, D.C., Cuchillo, H.M., and Pérez-Gil, R.F., 2009a. Effect of feeding management and seasonal variation on fatty acid composition of Mexican soft raw goats' milk cheese, Italian Journal of Animal Science, 8, 402-404.

Puga, D.C., Galina, H.M., Bonilla, C.A., Cuchillo, H.M., Montaño, B. S., Castillo, D.R., Villareal, E., and Pérez-Gil, R.F., 2009b. Effect of feeding management on the nutritional composition of Mexican artisan soft cheese made with raw or pasteurized goats' milk, Indian Journal of Animal Science, 79, 321-326.

Sanz Sampelayo, M.R., Chilliard, Y., Schmidely, P., and Boza, J., 2007. Influence of type of diet on the fat constituents of goat and sheep milk, Small Ruminant Research, 68, 42-63.

SAS - Statistical Analysis System, 2003. User's Guide: Statistics, (SAS, Cary, North Carolina.).

Vasta, V., Nudda, A., Cannas, A., Lanza, M., and Priolo, A., 2008. Alternative feed resources and their effects on the quality of meat and milk from small ruminants, Animal Feed Science and Technology, 147, 223-246. 